UDK: 159.923.072-057.875:371.26

378.6:351.74(497.11)

Pregledni rad

\title{
PREDICTION MODEL OF EFFECTIVE STUDIES AT THE ACADEMY OF CRIMINALISTIC AND POLICE STUDIES ${ }^{1}$
}

\author{
Sasa Milojevic ${ }^{2}$ \\ Bojan Jankovic ${ }^{3}$ \\ Vladimir Cvetkovic ${ }^{4}$ \\ Academy of Criminalistic and Police Studies, Belgrade
}

Summary: The paper deals with the connection between the input characteristics of students of the Academy of Criminalistic and Police Studies in Belgrade related to the acquired and inherited values and effective studying. Data collection was performed using the questionnaire technique on a sample of 120 students and the logic regression method. The questionnaire comprised 11 closed questions, 10 relating to predictor variables (gender, high school, success in high school, place in which it was finished, going in for sport, respondent's family and financial situation, whether a member of the family is employed by the Ministry of Interior and the course of studies), and one relating to the criterion variable (studying without repeating years). The results of logic regression showed that the overall model explains between $40.4 \%$ and $55.7 \%$ of variance in the status of effective studying, and it correctly classified $83.6 \%$ of cases. Only five predictor variables provided a unique statistically significant contribution to the model. The paper proved that if a student had a specific set of inherited and acquired characteristics, probability that he/she would study effectively is significantly

1 This paper is the result of the research on project: "Management of police organization in preventing and mitigating threats to security in the Republic of Serbia", which is financed and carried out by the Academy of Criminalistic and Police Studies, Belgrade - the cycle of scientific projects 2015-2019.

2 Corresponding author is Professor Saša Milojević, PhD, sasa.milojevic@kpa.edu.rs.

3 Bojan Janković, PhD, bojan.jankovic@kpa.edu.rs.

4 Vladimir Cvetkovic, MA, vladimir.cvetkovic@kpa.edu.rs. 
increased. The paper proved that higher police education institutions should pay attention to the inherited and acquired characteristics at the entrance examination. Unlike any previous research, the paper deals with desired characteristics modelling implying that the candidate has increased chances to study effectively.

Keywords: prediction model, effective study, acquired and inherited values, criminalistic and police studies.

\section{Introduction}

The selection and training of future police officers is a long-term, intensive and expensive process. Knowledge is at the centre of students' engagement with higher education. ${ }^{5}$ In an effort to improve the quality of new recruits, police organizations have adopted different techniques to identify the quality staff and eliminate unskilled candidates for policing. One way is to adopt a multistage testing, ${ }^{6}$ which includes: written tests, physical tests, oral interviews, vetting candidates, medical and psychological examinations, ${ }^{7}$ as well as the polygraph test. Another way that could affect the quality of police personnel was to employ a greater number of highly educated candidates. ${ }^{8}$ Several studies have shown that recruitment of new police officers who have a higher education can contribute to the better performance of certain police operations. ${ }^{9}$ Besides elimination of undesirable police candidates by selection process, some studies address the issue of predicting which candidates will be able to successfully complete the police academy (course for police officers). ${ }^{10}$ The research presented in this paper differs from similar studies as it relates to the prediction of effective study at higher education institutions for police education, which lasts for 3 or 4 years.

5 P. Ashwin, Knowledge, curriculum and student understanding in higher education, Higher Education, 67/2014, 123-126.

6 K. Gray, Problem behaviors of students pursuing policing careers, Policing: An International Journal of Police Strategies \& Management, Vol. 34/2011, No. 3, pp. 541-552.

7 J. Lough; V. Treuer, A critical review of psychological instruments used in police officer selection, Policing: An International Journal of Police Strategies \& Management, Vol. 36/2013, No. 4, pp. 737751;W. Weiss; U. Davis; R. Rostow; C. Kinsman, The MMPI-2 L Scale as a Tool in Police Selection, Journal of Police and Criminal Psychology, Vol. 18/2003, No. 1, pp. 57-60; R. Cochrane; T. Tett; L. Vandecreek, Psychological Testing and the Selection of Police Officers: A National Survey, Criminal Justice and Behavior,Vol. 30/2013, No. 5, pp. 511-537. K. Gray, Opus citatum; Y. Porath, Identifying Mmpi-2 Predictors of Police Officer Integrity and Misconduct, Criminal Justice and Behavior, Vol. 34/2007, No. 8, pp. 985-1004.

8 K. Gray, Opus citatum.

9 R. Roberg; S, Bonn, Higher Education and Policing: Where are we now?, Policing: An International Journal of Police Strategies \& Management, Vol. 27/2004, No. 4, pp. 469-486; S. Smith; M. Aamodt, The Relationship between Education, Experience, and Police performance, Journal of Police and Criminal Psychology, Vol. 12/1997, No. 2, pp. 7-14.

10 B. Wright; M. Dai; M. Greenbeck, Correlates of police academy success, Policing: An International Journal of Police Strategies \& Management, Vol. 34/2011, No. 4, pp. 625-637; D. Lester, Predictors of graduation from a police training academy, Psychological Reports, Vol. 44/1979, No. 2, pp. 362-362. 
Effectiveness is the ability to produce the desired results. ${ }^{11}$ When something is considered to be effective that means it has a desired outcome. ${ }^{12}$ Accordingly, an effective study means that the process of education at a higher education institution has the desired outcome - graduation with spending fewer resources (time, financial resources, etc.). Thus, the desired outcome of studies, or effective studies, is graduating "in a given term" or studying without repeating one or more school years. ${ }^{13}$

In Serbia, the Academy of Criminalistic and Police Studies as an institution of higher education was established by the Decision of the Government of Serbia ${ }^{14}$ to apply the curriculum of police education. ${ }^{15}$ This higher education institution was established as a legal successor of the Advanced School of Internal Affairs, formed in 1972, ${ }^{16}$ and Police Academy, formed in 1993. The Academy of Criminalistic and Police Studies is a member of the Association of European Police Colleges. The Academy of Criminalistic and Police Studies is the only stand-alone higher level education institution in Serbia accredited for performing criminalistic studies.

The Academy realizes many curricula, which, in addition to a number of theoretical parts, contain a considerable proportion of content enabling students to acquire practical knowledge and skills necessary to perform police duties. ${ }^{17}$ All theoretical contents studied at the Academy can be classified into general educational content (Sociology, Ethics, Economics, Foreign Language, etc.), contents of criminology (Criminology, Criminal Methodology, Crime Operations, etc.), legal content (Criminal Law, Misdemeanour Law, Administrative Law, etc.), security-related fields (International Security, National Security, Security in Emergencies, etc.), as well as police activities (organization and activities of the police, police tactics, technical resources of the police, etc.). On the other hand, the students of the Academy acquire practical knowledge and skills by the so-called specific forms of teaching. There are many of them, and they vary in content and style of performance, but the goal is the same - adoption of necessary practical knowledge and skills that serve as a "professional tool" to the graduates in performance of the police duties. ${ }^{18}$ Such demanding academic curricula necessitate that students, especially those who are studying effectively, have a number of desirable psychophysical characteristics (morphological characteristics, fundamental motor status, IQ, cognitive and conative abilities, endurance, perseverance, etc.).

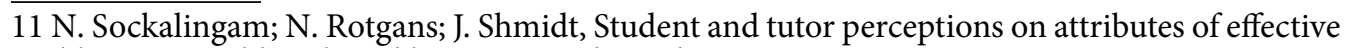
problems in problem-based learning, Higher Education, 62/2011,1-16.

12 S. Milojević, Osnovi policijske taktike, Kriminalističko-policijska akademija, Beograd, 2009.

13 S. Milojević; D. Subošić, Analiza primenjivosti znanja i veština koje se stiču na Policijskoj akademiji sa aspekta obavljanja policijske profesije, Nauka, bezbednost, policija, Vol. 2/2002, No. 7, pp. 67-98.

14 S. Milojević, Optimizacija modela posebnih oblika nastave na Kriminalističko-policijskoj akademiji, Bezbednost, Vol. 52/2010, No. 3, pp. 24-55.

15 G. Milošević; D. Subošić, Praktična obuka studenata u sistemu visokog policijskog obrazovanja Republike Srbije, Bezbednost, Vol. 52/2010, No. 1, pp. 154-171.

$16 \mathrm{~B}$. Banović, Viša škola unutrašnjih poslova u procesu reforme policijskog školstva, in "Okrugli sto o reformi policijskog školstva u Srbiji”, Beograd, Srbija, 2004, OEBS i Savet Evrope, Beograd, pp. 39-42.

17 S. Milojević; D. Subošić, Opus citatum.

18 Ibidem.

NBP • Journal of Criminalistics and Law [137] 
Police organizations around the world face the challenge of selecting the applicants who will become successful on-the-job performers. ${ }^{19}$ Determining whether a candidate for a student of the Academy has desirable psychophysical properties is conducted in the admission examination based on the announcement for admission. In addition to determining whether the applicant meets the requirements of the announcement, during the admission process, a series of data about the acquired and inherited values (gender, high school that the candidate has finished, whether the candidate goes in for sports, whether a candidate's close family member is employed at the Ministry of Interior and the like), while very few of them are used in deciding which candidate will be admitted to the Academy, and which will be refused. In addition to weeding out the unsuitable candidates, the selection process attempts to predict which candidates will be able to successfully complete the Academy. ${ }^{20}$

Given the above, with 20\% sample students of final years of the Academy, a research was conducted and the data were collected in order to answer the question whether or not the input characteristics of the Academy students, relating to the acquired and inherited values, can predict their effectiveness in the study. The obtained results are presented below.

\section{The sample and the applied methods}

Data collection was performed by the questionnaire technique ${ }^{21}$ on a stratified sample of 120 students of the Academy (randomly selected students of the third year of undergraduate vocational studies (63 or 52.5\%) and the fourth year of undergraduate academic studies (57 or 47.5\%). The questionnaire comprised 11 closed questions, 10 of which related to predictor variables in connection with the acquired and inherited characteristics (respondent's gender, high school the respondent finished, respondent's success in high school, place where the respondent finished high school, whether the respondent goes in for sport, respondent's family situation, respondent's financial situation, whether a member of the respondent's immediate family is employed by the Ministry of Interior and the course of studies the respondent enrolled), while one related to the dependent (criterion) variable (effectiveness of studying).

Since the aim of the research is to answer the question whether the effectiveness during studies may be predicted on the basis of the input characteristics of the Academy students, logistic regression ${ }^{22}$ was used while processing the collected data, since it enables testing a model for predicting categorical outcomes (effective studying or not). In order to apply logistic regression, the following assumptions are necessary to be satisfied: (1) sample size, (2) multicolinearity, and (3) atypical points.

19 J. Lough; V. Treuer, Opus citatum.

20 B. Wright; M. Dai; M. Greenbeck, Opus citatum.

21 N. Milošević; S. Milojević, Osnovi metodologije bezbednosnih nauka, Policijska akademija, Beograd, 2001.

22 G. Tabachnick; S. Fidell, Using multivariate statistic (5th edn.), Pearson Education, Boston, 2007. 
To satisfy the assumption on the size of the sample, it was necessary to recode the respondents' responses to questions about the finished high school and the place where the high school was finished. Recoding responses about the finished high school was made in such a way that all high schools listed by respondents were classified into four categories - grammar schools, high school of technical sciences (e.g., high school of mechanical engineering, high school of electrical engineering, high school of civil engineering, and the like), high school of natural sciences (high school of chemical science, medical high school, high school of veterinary and the like) and high schools of social sciences (high school of economics, law and administration high school, tourism management high school, etc.). Recoding of responses about the place where the respondent finished high school was performed in such a way that all the answers were classified into four categories according to the statistical regions the Republic of Serbia is divided into - (1) Vojvodina, (2) Belgrade, (3) Sumadija and Western Serbia, and (4) Southern and Eastern Serbia. After the recoding, the assumption on the size of the sample was satisfactory because in each category of variables there were sufficient number of cases, as can be seen from Table 1.

Table 1. Descriptive statistics of samples

\begin{tabular}{|c|c|c|c|}
\hline Variable & Categories & Frequency & Percent \\
\hline \multirow{3}{*}{ Gender } & Female & 40 & 33.3 \\
\hline & Male & 80 & 66.7 \\
\hline & $\begin{array}{l}\text { Total: } \\
\text { Grammar schools }\end{array}$ & $\frac{120}{34}$ & $\frac{100.0}{20.2}$ \\
\hline \multirow{3}{*}{ High school } & $\begin{array}{l}\text { Grammar schools } \\
\text { High schools of technical sciences }\end{array}$ & $\begin{array}{l}34 \\
21\end{array}$ & $\begin{array}{l}28.3 \\
17.5\end{array}$ \\
\hline & High schools of natural sciences & 18 & 15.0 \\
\hline & High schools of social sciences & 45 & 37.5 \\
\hline \multirow{3}{*}{ Success in high school } & $3.50-4.49$ & 61 & $\frac{90.3}{50.8}$ \\
\hline & $4.50-5.00$ & 57 & 47.5 \\
\hline & TOTAL & 118 & 98.3 \\
\hline \multirow{4}{*}{$\begin{array}{l}\text { Statistical region in } \\
\text { which the respondent } \\
\text { finished high school }\end{array}$} & $\frac{\text { Vojvodina }}{\text { Bêlgrade }}$ & $\frac{25}{15}$ & $\frac{20.8}{12.5}$ \\
\hline & Sumadija and Western Serbia & 43 & 35.8 \\
\hline & Southern and Eastern Serbia & 34 & 28.3 \\
\hline & Total: & 117 & 96.4 \\
\hline \multirow{2}{*}{$\begin{array}{l}\text { Respondent goes in for } \\
\text { sports }\end{array}$} & Yes & 65 & 54.2 \\
\hline & $\frac{\text { No }}{\text { TOTAL }}$ & $\frac{55}{120}$ & $\frac{45.8}{100.0}$ \\
\hline \multirow{3}{*}{$\begin{array}{l}\text { Family situation of the } \\
\text { respondent }\end{array}$} & Lives with both & 99 & 82.5 \\
\hline & $\begin{array}{c}\text { parents } \\
\text { Lives with single parent }\end{array}$ & 21 & 175 \\
\hline & $\begin{array}{l}\text { Lives winn a singie parent } \\
\text { Total: }\end{array}$ & $\frac{21}{120}$ & $\frac{17.5}{100.0}$ \\
\hline \multirow{4}{*}{$\begin{array}{l}\text { Financial situation of the } \\
\text { respondent/Closer family } \\
\text { member works in the } \\
\text { Police }\end{array}$} & Good & 54 & 45.0 \\
\hline & $\frac{\text { Bad }}{\text { TOTAL }}$ & $\frac{64}{118}$ & $\begin{array}{l}53.3 \\
98.3\end{array}$ \\
\hline & Yes & 27 & 22.5 \\
\hline & $\frac{N e}{\text { Total. }}$ & $\frac{93}{120}$ & $\frac{77.5}{1000}$ \\
\hline \multirow{2}{*}{$\begin{array}{c}\text { Course of study of the } \\
\text { respondent }\end{array}$} & Vocational studies & 63 & 52.5 \\
\hline & $\begin{array}{c}\text { Academic studies } \\
\text { Total: }\end{array}$ & $\frac{57}{120}$ & $\frac{47.5}{100.0}$ \\
\hline \multirow{2}{*}{ Repeating a year } & Yes & 41 & 34.2 \\
\hline & No & $\frac{78}{119}$ & $\frac{65.0}{992}$ \\
\hline
\end{tabular}

The assumption of multicolinearity is also not violated because in the diagnosis of colinearity, given in Table 2, values of the coefficient of tolerance and the magnification variance factor are within permitted limits (tolerance $0>$ 0.10 , and the magnification variance factor $<10$ ). 
Sasa Milojevic, Bojan Jankovic, Vladimir Cvetkovic

Table 2. Diagnostics of colinearity

\begin{tabular}{|c|c|c|}
\hline \multirow{2}{*}{} & \multicolumn{2}{|c|}{ Colinearity Statistics } \\
\cline { 2 - 3 } & Tolerance & VIF \\
\hline Gender & .897 & 1.115 \\
\hline High school & .969 & 1.032 \\
\hline Success & .829 & 1.206 \\
\hline Statistical region & .878 & 1.139 \\
\hline Sport & .890 & 1.123 \\
\hline Family situation & .882 & 1.133 \\
\hline Financial situation & .923 & 1.083 \\
\hline $\begin{array}{c}\text { Family member employed by the } \\
\text { Ministry of Interior }\end{array}$ & .920 & 1.087 \\
\hline Course of study & .862 & 1.160 \\
\hline
\end{tabular}

Finally, the assumption of the absence of non-typical points was also confirmed by examination of Mahalanobis distances of residuals (the values of which are given in Table 3 ), since the model that was examined had 10 predictor variables, so that the maximum value of Mahalanobis distance is 24.144 , smaller than the table critical (maximum allowed) value. ${ }^{23}$

Table 3. Descriptive statistics of residual

\begin{tabular}{|c|c|c|c|c|c|}
\hline \multirow{2}{*}{ Predicted Value } & Min. & Max. & Mean & Std. Dev. & N \\
\cline { 2 - 6 } & .23 & 1.18 & .66 & .295 & 110 \\
\hline Std. Predicted Value & -1.463 & 1.775 & .024 & 1.004 & 110 \\
\hline $\begin{array}{c}\text { Standard Error of Predicted } \\
\text { Value }\end{array}$ & .087 & .186 & .121 & .021 & 110 \\
\hline Adjusted Predicted Value & .17 & 1.19 & .66 & .299 & 110 \\
\hline Residual & -.928 & .725 & -.008 & .381 & 110 \\
\hline Std. Residual & -2.354 & 1.839 & -.020 & .967 & 110 \\
\hline Stud. Residual & Min. & Max. & Mean & Std. Dev. & N \\
\cline { 2 - 6 } & -2.451 & 1.967 & -.019 & 1.017 & 110 \\
\hline Deleted Residual & -1.006 & .832 & -.007 & .422 & 110 \\
\hline Stud. Deleted Residual & -2.514 & 1.995 & -.018 & 1.023 & 110 \\
\hline Mahal. Distance & 4.535 & 24.144 & 9.978 & 4.099 & 110 \\
\hline Cook's Distance & .000 & .076 & .010 & .013 & 110 \\
\hline Centred Leverage Value & .040 & .214 & .088 & .036 & 110 \\
\hline
\end{tabular}

Thus, all initial assumptions for the application of logistic regression are met. Accordingly, logistic regression will be used to analyze the ability of the model consisting of students' input characteristics to make prediction of the effectiveness of their studying.

23 J. Goodwin, Research in psychology: Methods and design (5th edn), New York, 2004, John Wiley.

[140] NBP • Žurnal za kriminalistiku i pravo 


\section{Results}

The results of logistic regression used to examine power of the model consisting of inherited and acquired input characteristics of a student to predict the outcome of effectiveness of studying are given in the following tables.

Table 4. Results of predicting effectiveness outcome in the zero step

\begin{tabular}{|c|c|c|c|c|c|}
\hline \multirow{2}{*}{\multicolumn{3}{|c|}{ Observed }} & \multicolumn{3}{|c|}{ Predicted } \\
\hline & & & \multicolumn{2}{|c|}{$\begin{array}{l}\text { Whether a respondent repeat- } \\
\text { ed a year }\end{array}$} & \multirow{2}{*}{$\begin{array}{l}\text { Percentage } \\
\text { Correct }\end{array}$} \\
\hline & & & Yes & No & \\
\hline \multirow{3}{*}{$\begin{array}{c}\text { Step } \\
0\end{array}$} & \multirow{2}{*}{$\begin{array}{c}\text { Whether a respondent repeat- } \\
\text { ed a year }\end{array}$} & Yes & 0 & 38 & .0 \\
\hline & & No & 0 & 72 & 100.0 \\
\hline & \multicolumn{2}{|l|}{ Overall Percentage } & & & 65.5 \\
\hline
\end{tabular}

Table 4 presents the results of the analysis without any predictor variables comprising the model. They are used to compare the model results that contain them. The table indicates that there were $65.5 \%$ correctly classified cases. Because most of the respondents study regularly without repeating the school year, in the initial (zero) step, it was assumed that not all respondents would repeat the school year during the study.

Table 5. Aggregate performance indicators of the model

\begin{tabular}{|c|c|c|c|c|}
\hline \multicolumn{2}{|c|}{} & Chi-square & df & Sig. \\
\hline \multirow{3}{*}{ Step 1 } & Step & 56.848 & 14 & .000 \\
\cline { 2 - 5 } & Block & 56.848 & 14 & .000 \\
\cline { 2 - 5 } & Model & 56.848 & 14 & .000 \\
\hline
\end{tabular}

Table 5 presents differences between the models we have analyzed (composed of predictor variables) and the results obtained in the initial (zero) step, when there were no predictor variables in the model. In other words, the table is composed of indicators showing how well the model predicts the results. Since the significance is less than 0.0005 , the model with a set of variables as predictors predicts the final result (effectiveness of study) better than the initial prediction without predictor variables. Indicator $\chi^{2}$ is 56.848 with 14 degrees of freedom.

Table 6. Hosmer and Lemeshow Test

\begin{tabular}{|c|c|c|c|}
\hline Step & Chi-square & df & Sig. \\
\hline 1 & 5.094 & 8 & .747 \\
\hline
\end{tabular}

Hosmer and Lemeshow test, the results of which are presented in Table 6, supports the assumption that the model is good. In this test, an indicator of poor predicting is the significance lower than 0.05 . The Table 6 indicator $\chi^{2}$ for Hosmer and Lemeshow test is 5.094, with significance 0.747. It is more than 0.05, which means that the test supports the model. 
Sasa Milojevic, Bojan Jankovic, Vladimir Cvetkovic

Table 7. Summary data of the model

\begin{tabular}{|c|c|c|}
\hline Step & Cox \& Snell R Square & Nagelkerke R Square \\
\hline 1 & .404 & .557 \\
\hline
\end{tabular}

Table 7 presents the values of Cox-Snell R square and Nagelkerke R square that show which part of the criterion variable variance the model explains. In the table, these two indicators are 0.404 and 0.557 , which means that a given set of variables (model) explains between $40.4 \%$ and $55.7 \%$ of the variance.

Table 8. Results of predicting the outcome of effectiveness

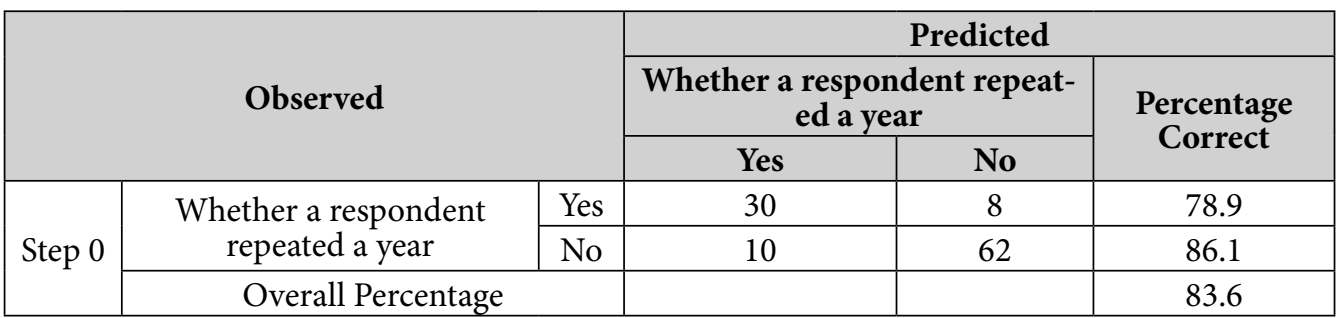

Table 8 shows the results of logistic regression when all predictor variables were included in the analysis. There are indicators of how accurately the model predicts the category (the respondent repeats the academic years/the respondent studies regularly without repeating school years) for each tested case. When these results are compared with the results given in Table 4 (without predictor variables included in the model), we observe a significant improvement achieved by the inclusion of predictor variables in the model. Now, the model correctly classifies $83.6 \%$ of all cases, which is better than $65.5 \%$ reported in the Table 4 . Sensitivity of the model is great because it correctly classifies $86.1 \%$ of respondents who regularly study without repeating the school year. Determination of the model is also great because it correctly classifies $78.9 \%$ of respondents who repeat the school year. A positive predictive value of the model is $88.5 \%$, which shows that the model accurately picks $88.5 \%$ of respondents who are predicted to regularly study without repeating school years. A negative predictive value of the model is $75 \%$, which means that the model shall classify $75 \%$ of respondents as those who repeat the school year, and that is true. Table 9 provides the information on the contribution (importance) of each predictor variable. Based on the values in the column Sig., the variables that significantly contribute to the predictive capabilities of the model are: (1) respondent's gender; (2) whether the respondent finished grammar school; (3) whether the respondent finished high school of natural sciences; (4) whether the respondent goes in for sport, and (5) what the financial situation of the respondent is like. Other predictor variables did not significantly contribute to the model. B coefficients for all predictor variables that significantly affect the power of the model are positive, which means that (since these are categorical variables) the existence of an attribute of a variable increases probability that a student will study effectively. Probability ratios for significant predictor variables show that there is a greater probability that the student will study effectively if he is male, if he finished grammar school or high school of natural sciences, if he goes in for sport, and if his financial situation is bad. 
PREDICTION MODEL OF EFFECTIVE STUDIES AT THE ACADEMY OF CRIMINALISTIC...

Table 9. Predicting the probability that the respondent regularly studies without repeating school years

\begin{tabular}{|c|c|c|c|c|c|c|c|c|}
\hline & \multirow[t]{2}{*}{ B } & \multirow[t]{2}{*}{ S.E. } & \multirow[t]{2}{*}{ Wald } & \multirow[t]{2}{*}{ df } & \multirow[t]{2}{*}{ Sig. } & \multirow[t]{2}{*}{$\operatorname{Exp}(B)$} & \multicolumn{2}{|c|}{$\begin{array}{l}\text { 95\% C.I.for EX- } \\
\text { P(B) }\end{array}$} \\
\hline & & & & & & & Lower & Upper \\
\hline Gender & .716 & .339 & 4.464 & 1 & .035 & 2.046 & 1.053 & 3.976 \\
\hline Grammar school & 1.98 & .325 & 37.31 & 1 & .000 & 7.274 & 3.848 & 13.74 \\
\hline \multirow[t]{3}{*}{$\begin{array}{c}\text { High schools of technical } \\
\text { sciences }\end{array}$} & .151 & .851 & .031 & 1 & .859 & 1.163 & .219 & 6.162 \\
\hline & \multirow[t]{2}{*}{ B } & \multirow[t]{2}{*}{ S.E. } & \multirow[t]{2}{*}{ Wald } & \multirow[t]{2}{*}{ df } & \multirow[t]{2}{*}{ Sig. } & \multirow[t]{2}{*}{$\operatorname{Exp}(B)$} & \multicolumn{2}{|c|}{$\begin{array}{l}\text { 95\% C.I.for EX- } \\
\text { P(B) }\end{array}$} \\
\hline & & & & & & & Lower & Upper \\
\hline $\begin{array}{c}\text { High schools of natural } \\
\text { sciences }\end{array}$ & .448 & .165 & 7.366 & 1 & .007 & 1.639 & .462 & .883 \\
\hline $\begin{array}{l}\text { High schools of social } \\
\text { sciences }\end{array}$ & -.522 & .730 & .510 & 1 & .475 & .593 & .142 & 2.484 \\
\hline Success & -.191 & .607 & .099 & 1 & .754 & .826 & .251 & 2.718 \\
\hline Vojvodina & & & 3.788 & 3 & .285 & & & \\
\hline Belgrade & 1.362 & 1.078 & 1.595 & 1 & .207 & 3.905 & .472 & 32.321 \\
\hline $\begin{array}{l}\text { Sumadija and Western } \\
\text { Serbia }\end{array}$ & -.533 & .788 & .458 & 1 & .499 & .587 & .125 & 2.749 \\
\hline $\begin{array}{c}\text { Southern and Eastern } \\
\text { Serbia }\end{array}$ & .215 & .838 & .066 & 1 & .797 & 1.240 & .240 & 6.411 \\
\hline $\begin{array}{l}\text { Whether the respondent } \\
\text { goes in for sport }\end{array}$ & .398 & .178 & 6.243 & 1 & .011 & 2.712 & .332 & .743 \\
\hline Family situation & -.614 & 1.088 & .318 & 1 & .573 & .541 & .064 & 4.571 \\
\hline Financial situation & .826 & .228 & 5.164 & 1 & .003 & 3.136 & 1.122 & 3.872 \\
\hline $\begin{array}{l}\text { Family member works in } \\
\text { the Police }\end{array}$ & -1.113 & .831 & 1.794 & 1 & .180 & .329 & .064 & 1.675 \\
\hline Course of study & .275 & .593 & .216 & 1 & .642 & 1.317 & .412 & 4.208 \\
\hline Constant & 5.493 & 1.888 & 8.465 & 1 & .004 & 243.102 & & \\
\hline
\end{tabular}

\section{Discussion and conclusion}

Summarizing the results, it can be concluded that the direct logistic regression was conducted to assess the influence of various factors on the probability that a student of the Academy will study effectively. A predictive model comprises ten predictor variables (gender, type of high school the respondent finished, the respondent's success in high school, the statistical region in which the respondent finished high school, whether the respondent goes in for sport, the respondent's family situation, the respondent's financial situation, whether any of the respondent's immediate family members is employed by the Ministry of Interior, and the respondent's course of study). The whole model (with all predictors) was statistically significant $\chi^{2}(14, \mathrm{~N}=110)=56.848, \mathrm{p}<0.0005$, which shows that the model divides subjects into those who study effectively and 
those who repeated one or more school years during the study. As a whole, the model explains between 40.4\% (Cox - Snell R Square) and 55.7\% (Nagelkerke R Square) of the variance in the status of effective study, and it correctly classifies $83.6 \%$ of cases.

Only five predictor variables gave a unique statistically significant contribution to the model (male, finished high school, finished high school of natural sciences, going in for sport, and bad financial situation). The strongest predictor of effective study is finished grammar school, and then the following: bad financial situation of the respondent, finished high school of natural sciences, going in for sport, and, in the end, the respondent's gender. The results show that, with all other factors equal in the model, probability that the student will study effectively is greater if the respondent: (1) is male - 2.046 times, (2) finished grammar school - 7.274 times (in comparison to all other schools), (3) finished high school of natural sciences (in relation to schools of technical and social sciences) - 1.639 times, (4) goes in for sports 2.712, and (5) his financial situation is bad -3.136 times.

The Academy of Criminalistic and Police Studies is a specific institution of higher education, which is, in a way, a hybrid of the Faculty of Law, Faculty of Sport, Faculty of Security Studies, and the Military Academy, with a specificity related to the study of Criminal Justice Sciences. The results obtained by the conducted research confirm that specific students, specific both by their psychophysical characteristics, and by the acquired and inherited characteristics, attend a specific institution.

It is rather surprising that the probability of more effective study is greater if the student has finished grammar school, or high school of natural sciences. The Curricula of the Academy of Criminalistic and Police Studies mostly belong to social and human sciences, so it would be logical that students who finished high schools of social sciences would complete the curriculum easier and faster. Why it is not like that may be the subject of a new research, but the assumption is that in grammar schools and high schools of natural sciences students "learn how to learn" better than in other schools, which later influences the process of studying.

Bad financial situation is a strong motivating factor that drives students to study effectively. Students who are aware that they have insufficient financial support for higher education are more responsible and treat their obligations arising from the curriculum more seriously, and therefore study more effectively. This is probably not specific for the Academy only, but can be applied to all universities in Serbia. That can also be the subject of a new research.

Since in the curricula taught at the Academy there is a special emphasis on the skills and habits necessary for performing the police duties, it is necessary for the students to be physically fit, because skills and habits are acquired by training, and training in the police usually implies increased physical stress. Therefore, the students who go in for sports are more physically fit than those who do not, and that is why they complete the parts of the curriculum more easily, thus studying more effectively.

Although the Academy has been accepting female students for more than a decade, it seems that female students' assessment criteria, particularly in the parts 
of the curriculum (skills) in which physical constitution has a significant influence (special physical education, field training, police tactics, police topography, etc.) have not been adequately established yet, reflecting as a statistically significant contribution to the described model.

This paper has demonstrated that if a student has a specific set of inherited and acquired characteristics, the probability of effective study at the Academy greatly increases. Bearing this in mind, the Academy of Criminalistic and Police Studies, as well as similar institutions of higher education, should pay attention to inherited and acquired characteristics so that a candidate at the admission may be classified into the group of students with higher probability to study more effectively.

\section{References}

1. B. Banović, Viša škola unutrašnjih poslova u procesu reforme policijskog školstva, in "Okrugli sto o reformi policijskog školstva u Srbiji”, Beograd, Srbija, 2004, OEBS i Savet Evrope, Beograd, pp. 39-42.

2. B. Wright; M. Dai; M. Greenbeck, Correlates of police academy success, Policing: An International Journal of Police Strategies \& Management, Vol. 34/2011, No. 4, pp. 625-637.

3. D. Lester, Predictors of graduation from a police training academy, Psychological Reports, Vol. 44/1979, No. 2, pp. 362-362.

4. D. Richardson; S. Cave; L. Grange, Prediction of Police Officer Performance Among New Mexico State Police as Assessed by the Personality Assessment Inventory, Journal of Police and Criminal Psychology, Vol. 22/2007, No. 2, pp. 84-90.

5. E. Paoline; W. Terrill, Police Education, Experience, and the Use of Force , Criminal Justice and Behavior,Vol. 34/2007, No. 2, pp. 179-196.

6. G. Kayihan; G. Ersoz; G. Ozkan; A. Koz, Relationship between efficiency of pistol shooting and selected physical-physiological parameters of police, Policing: An International Journal of Police Strategies \& Management, Vol. 36/2013, No. 4, pp. 819-832.

7. G. Milošević; D. Subošić, Praktična obuka studenata u sistemu visokog policijskog obrazovanja Republike Srbije, Bezbednost, Vol. 52/2010, No. 1, pp. 154-171.

8. G. Tabachnick; S. Fidell, Using multivariate statistic (5th edn.), Pearson Education, Boston, 2007.

9. J. Goodwin, Research in psychology: Methods and desing (5th edn), New York, 2004, John Wiley.

10. J. Lough; V. Treuer, A critical review of psychological instruments used in police officer selection, Policing: An International Journal of Police Strategies \& Management, Vol. 36/2013, No. 4, pp. 737-751.

11. K. Gray, Problem behaviors of students pursuing policing careers, Policing: An International Journal of Police Strategies \& Management, Vol. 34/2011, No. 3, pp. 541-552. 
12. M. Sellbom; G. Fischler; Y. Porath, Identifying Mmpi-2 Predictors of Police Officer Integrity and Misconduct, Criminal Justice and Behavior, Vol. 34/2007, No. 8, pp. 985-1004.

13. N. Milošević; S. Milojević, Osnovi metodologije bezbednosnih nauka, Policijska akademija, Beograd, 2001.

14. N. Sockalingam; N. Rotgans; J. Shmidt, Student and tutor perceptions on attributes of effective problems in problem-based learning, Higher Education, 62/2011,1-16.

15. P. Ashwin, Knowledge, curriculum and student understanding in higher education, Higher Education, 67/2014, 123-126.

16. R. Cochrane; T. Tett; L. Vandecreek,Psychological Testing and the Selection of Police Officers: A National Survey, Criminal Justice and Behavior,Vol. 30/2013, No. 5, pp. 511-537.

17. R. Roberg; S, Bonn, Higher Education and Policing: Where are we now?, Policing: An International Journal of Police Strategies \& Management, Vol. 27/2004, No. 4, pp. 469-486.

18. S. Milojević, Optimizacija modela posebnih oblika nastave na Kriminalističkopolicijskoj akademiji, Bezbednost, Vol. 52/2010, No. 3, pp. 24-55.

19. S. Milojević, Osnovi policijske taktike, Kriminalističko-policijska akademija, Beograd, 2009.

20. S. Milojević; D. Subošić, Analiza primenjivosti znanja i veština koje se stiču na Policijskoj akademiji sa aspekta obavljanja policijske profesije, Nauka, bezbednost, policija, Vol. 2/2002, No. 7, pp. 67-98.

21. S. Milojević; G. Vučković; B. Janković, Analiza stavova studenata Kriminalističko-policijske akademije o efektivnosti terenske obuke u letnjim uslovima, Bezbednost, Vol. 53/2011, No 2, pp. 46-65.

22. S. Smith; M. Aamodt, The Relationship between Education, Experience, and Police performance, Journal of Police and Criminal Psychology, Vol. 12/1997, No. 2, pp. 7-14.

23. W. Weiss; U. Davis; R. Rostow; C. Kinsman, The MMPI-2 L Scale as a Tool in Police Selection, Journal of Police and Criminal Psychology, Vol. 18/2003, No. 1, pp. 57-60. 


\title{
MODEL PREDIKCIJE EFEKTIVNOG STUDIRANJA NA KRIMINALISTIČKO-POLICIJSKOJ AKADEMIJI U BEOGRADU
}

\author{
Saša Milojević \\ Bojan Janković \\ Vladimir Cvetković \\ Kriminalističko-policijska akademija, Beograd
}

Sažetak: Rad odgovara na pitanje da li se na osnovu ulaznih karakteristika studenata Akademije, koje se odnose na stečene i nasleđene vrednosti, može predvideti njihova efektivnost tokom studiranja. Odgovor na postavljeno pitanje potražen je realizacijom istraživanja sa studentima Kriminalističko-policijske akademije. Pri obradi prikupljenih podataka iskorišćena je logička regresija koja omogućava ispitivanje modela za predikciju kategorijskih ishoda (efektivno studira ili ne). Ispitivani model se sastojao od 10 prediktorskih varijabli (pol ispitanika, vrsta srednje škole koju je ispitanik završio, uspeh ispitanika u srednjoj školi, statistički region u kome je ispitanik završio srednju školu, da li se ispitanik bavi sportom, porodična situacija ispitanika, materijalna situacija ispitanika, da li je neki od ispitanikovih bližih članova porodice zaposlen u MUP-u i vrsta studija koju ispitanik pohađa). Rezultati logičke regresije pokazali su da model u celini objašnjava između $40.4 \%$ i $55.7 \%$ varijanse u statusu efektivnog studiranja i tačno klasifikuje $83.6 \%$ slučajeva. Samo pet prediktorskih varijabli dale su jedinstven statistički značajan doprinos modelu (muški pol, završena gimnazija, završena srednja škola prirodnih nauka, bavljenje sportom i lošiji materijalni status). U skladu sa tim rezultatima, u radu je dokazano da ukoliko student ima specifičan set nasleđenih i stečenih karakteristika vezanih za statistički značajne prediktorske varijable, uveliko se povećava verovatnoća da će efektivno studirati na Kriminalističko-policijskoj akademiji.

Ključne reči: model predikcije, efektivno studiranje, logička regresija, Kriminalističko-policijska akademija. 